\title{
The influence of coal mining on radon potential (*)
}

\author{
S. FEIGE and J. WiEGAND \\ University of Essen, Department 9, Geology - 45117 Essen (Germany)
}

(ricevuto il 9 Giugno 1998; approvato il 18 Novembre 1998)

\begin{abstract}
Summary. - Pit waters from hard-coal and brown-coal mining as well as sediments and soils along sewers and rivers in the vicinity of collieries are investigated in the scope of radiation protection. The greatest amount of ${ }^{226} \mathrm{Ra}$ is discharged by hard-coal collieries in the order of several ten $\mathrm{Bq} \mathrm{l}^{-1}$ at simultaneous occurrence of high mineralised brines. In contact with sulphate-bearing surface water, ${ }^{226} \mathrm{Ra}$ co-precipitates with $\mathrm{Ba}$ and is deposited as radiobarite. The contamination with ${ }^{226} \mathrm{Ra}$ leads to high activity concentrations and increased gamma dose rates. The special situation of diadochic incorporation of ${ }^{226} \mathrm{Ra}$ into the dense crystal lattice prevents ${ }^{222} \mathrm{Rn}$ from emanating. However in sediments influenced by brown-coal mining ${ }^{226} \mathrm{Ra}$ is adsorbed at the surfaces of ferric hydroxides and, therefore, ${ }^{222} \mathrm{Rn}$ can easily emanate.
\end{abstract}

PACS 92.40.Qk - Hydrology and glaciology.

PACS 29.40 - Radiation detectors.

PACS 01.30.Cc - Conference proceedings.

\section{1. - Introduction}

The hard- and brown-coal mining in North Rhine Westphalia (NRW), western Germany, involves the mining of large volumes of pit water caused by mine dewatering. Former investigations have shown that especially the high mineralised brines carry high concentrations of ${ }^{226} \mathrm{Ra}$ [1]. This phenomenon is also well described for the Upper Silesian Coal Basin [2] as well as for the brines from oil deposits [3]. The origin of such ${ }^{226} \mathrm{Ra}$-bearing brines is still solved unsatisfyingly.

We investigated the output of radionuclides all over the mean coal mining districts in NRW. Beside the identification and quantification of sources and sinks it was also an aim of the research project to prove the mechanism of ${ }^{226} \mathrm{Ra}$ leaching and transport and the availability of ${ }^{222} \mathrm{Rn}$.

(*) Paper presented at the "Fourth International Conference on Rare Gas Geochemistry", Rome, October 8-10, 1997. 


\section{2. - Methods and materials}

21. Site description. - Coal mining in NRW has to be subdivided into four districts: a) Open mining of brown-coal in large scales in the Lower Rhine area, b) now abandoned hard-coal mining in the Aachen-Erkelenzer district, c) hard-coal mining in progress in pits in the Ibbenbürener district and d) the most important hard-coal pit mining Ruhr district, also in progress.

2:2. Field work. - The waters to be analysed were collected up- and downstream from the discharge point in a river as well as the pit water itself. At every sampling point water temperature, $p \mathrm{H}$ and conductivity were measured to establish the origin of the analysed water. To judge the contamination of sediments and overbank deposits measuring profiles were put crosswise to the direction of the riverflow, whereby the soil which is not influenced by a river flood represents the geogenic background and could be compared to sediments and overbank deposits. After removing the overlying vegetation soil samples were taken at the place of interest from the upper $5 \mathrm{~cm}$.

2:3. Field and labortory analysis. - The determination of ${ }^{226} \mathrm{Ra}$ activity concentrations in waters was performed using the radon emanation technique [4]. ${ }^{226} \mathrm{Ra}$ was co-precipitated with $\mathrm{BaSO}_{4}$ and dissolved in Na-EDTA. After sealing for several days the sample was degassed and ${ }^{222} \mathrm{Rn}$ was transferred quantitatively into an evacuated counting cell [5]. ${ }^{222} \mathrm{Rn}$ was measured scintillometrically, the counts were corrected for background, decay and equilibrium conditions.

The ${ }^{222} \mathrm{Rn}$ activity concentration in the water was also analysed by using Lucas-cells after degassing the sample with a radon bubbler [4]. The ${ }^{226} \mathrm{Ra}$ activity concentration in soil samples and sediments was measured using a high-resolution HPGe detector. The samples were placed and sealed in Marinelli beakers. The activity was calculated using the lines of emission of ${ }^{222} \mathrm{Rn}$ daughter isotopes. To prove the ${ }^{222} \mathrm{Rn}$ emanation rate of a soil sample the material was sealed in a PET-chamber under water saturation to reach the maximum level of emanation [6]. After sealing over a period of time to reach equilibrium conditions an air sample was transferred into a Lucas cell and measured as described before. To calculate the ${ }^{222} \mathrm{Rn}$ flux from the soil surface the exhalated soil air was sampled over a defined period of time using an accumulator method [7]. Additionally, soil moisture and grain size were analysed at each sampling point. The total gamma activity of the ground was determinated by short-time measurements with a field scintillometer and expressed as surface dose [kcpm]. The determination of minerals was done by X-ray diffractometry.

\section{3. - Results}

$3 \cdot 1 .{ }^{226} R$ a concentration of pit water. - The average concentration of ${ }^{226} \mathrm{Ra}$ in surface water in Germany is known to be about $5 \mathrm{mBq}^{-1}$ [1]. The high mineralised brines released by hard-coal mines in the Ruhr district contain, in relation to the depth from which they are pumped up, a high concentration of $\mathrm{Ba}$ (up to $2500 \mathrm{mg} \mathrm{l^{-1 }}$; [8]) and increased concentrations of ${ }^{226} \mathrm{Ra}$. Sulphate is absent in such ${ }^{226} \mathrm{Ra}$-bearing waters. The pit water is released into sewers with concentrations up to $13 \mathrm{~Bq}^{226} \mathrm{Ra} \mathrm{l}^{-1}$. The yearly emission of ${ }^{226} \mathrm{Ra}$ through high mineralised brines released by collieries in the Ruhr district reaches values up to $200 \mathrm{GBq} \mathrm{a}^{-1}$, probably over $300 \mathrm{GBq} \mathrm{a}^{-1}$. Enhanced ${ }^{226} \mathrm{Ra}$ concentrations are also detected in the Erkelenzer hard-coal mining district: In a 
tributary downstream a colliery the ${ }^{226} \mathrm{Ra}$ concentration was analysed with a maximum value of nearly $1 \mathrm{~Bq}^{-1}$.

The less mineralised pit waters released by brown-coal mining also show increased ${ }^{226} \mathrm{Ra}$ concentrations. They reach maximum values of $37 \mathrm{mBq}^{-1}$, so less than in the hard-coal mining district. Because of the very large volume of released water (about 1.2 billion $\mathrm{m}^{3} \mathrm{a}^{-1}$ ) the yearly emission comes up to $20 \mathrm{GBq} \mathrm{a}^{-1}$ [1]. Recent studies have shown that the content of ${ }^{226} \mathrm{Ra}$ in the mined water may reach concentrations of $100 \mathrm{mBq} \mathrm{l}^{-1}$. In accordance with these values the yearly emission of ${ }^{226} \mathrm{Ra}$ through brown-coal mining in the Lower Rhine Area may exceed even $100 \mathrm{GBq} \mathrm{a}^{-1}$.

Other naturally occurring radionuclides from the ${ }^{238} \mathrm{U}$ decay series were not found to be in disequilibrium with ${ }^{238} \mathrm{U}$ except all ${ }^{226} \mathrm{Ra}$ daughters [9].

$3 \cdot 2 .{ }^{226} R$ a concentration of sediments and soils. - In contact with sulphate-bearing surface water, ${ }^{226} \mathrm{Ra}$ co-precipitates with $\mathrm{Ba}$ to radiobarite which sedimentates along the banks of sewers and rivers and accumulates as well in sewage sludge formed in clarification plants. The contamination with ${ }^{226} \mathrm{Ra}$ in chemical sediments near the discharge point of a colliery near Marl reaches levels of about $32000 \mathrm{~Bq} \mathrm{~kg}{ }^{-1}$. The

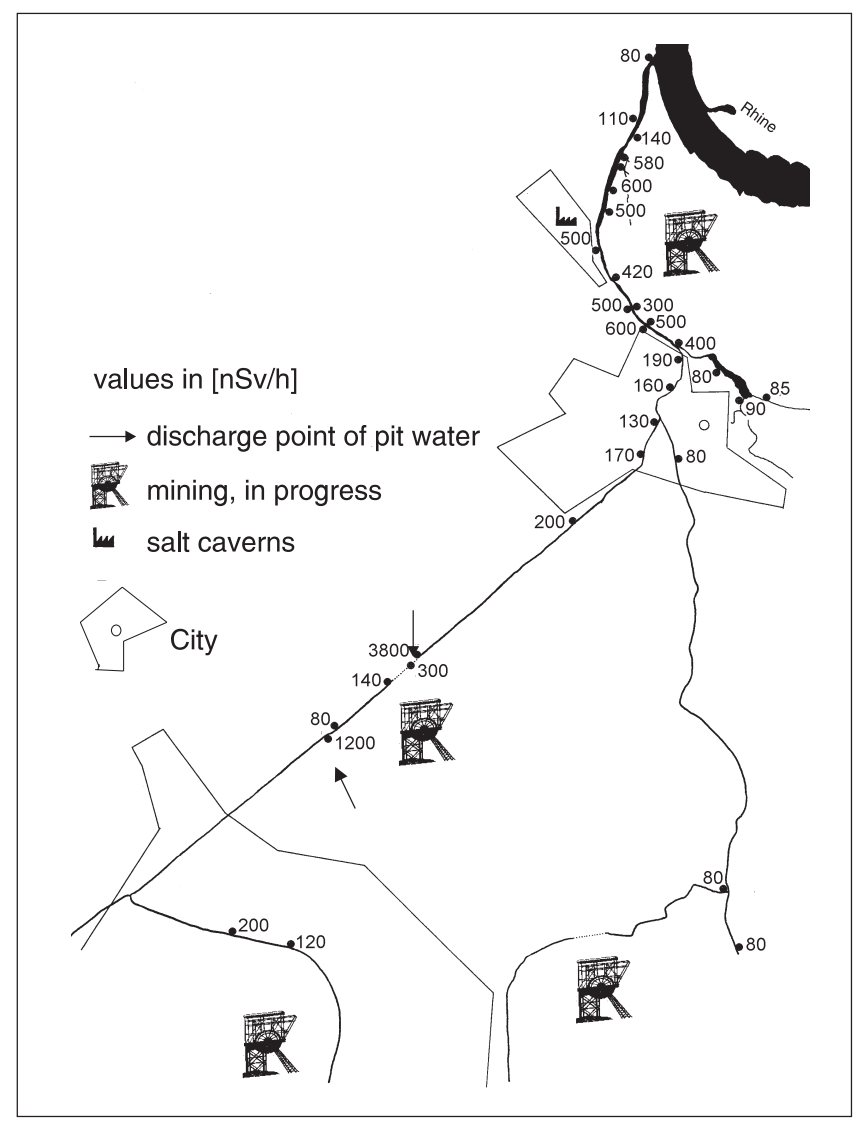

Fig. 1. - Enhanced total gamma-radiation of sediments and soils caused by the discharge of Ra-226-rich pit water from hard-coal mines in the north-western Ruhr district. 


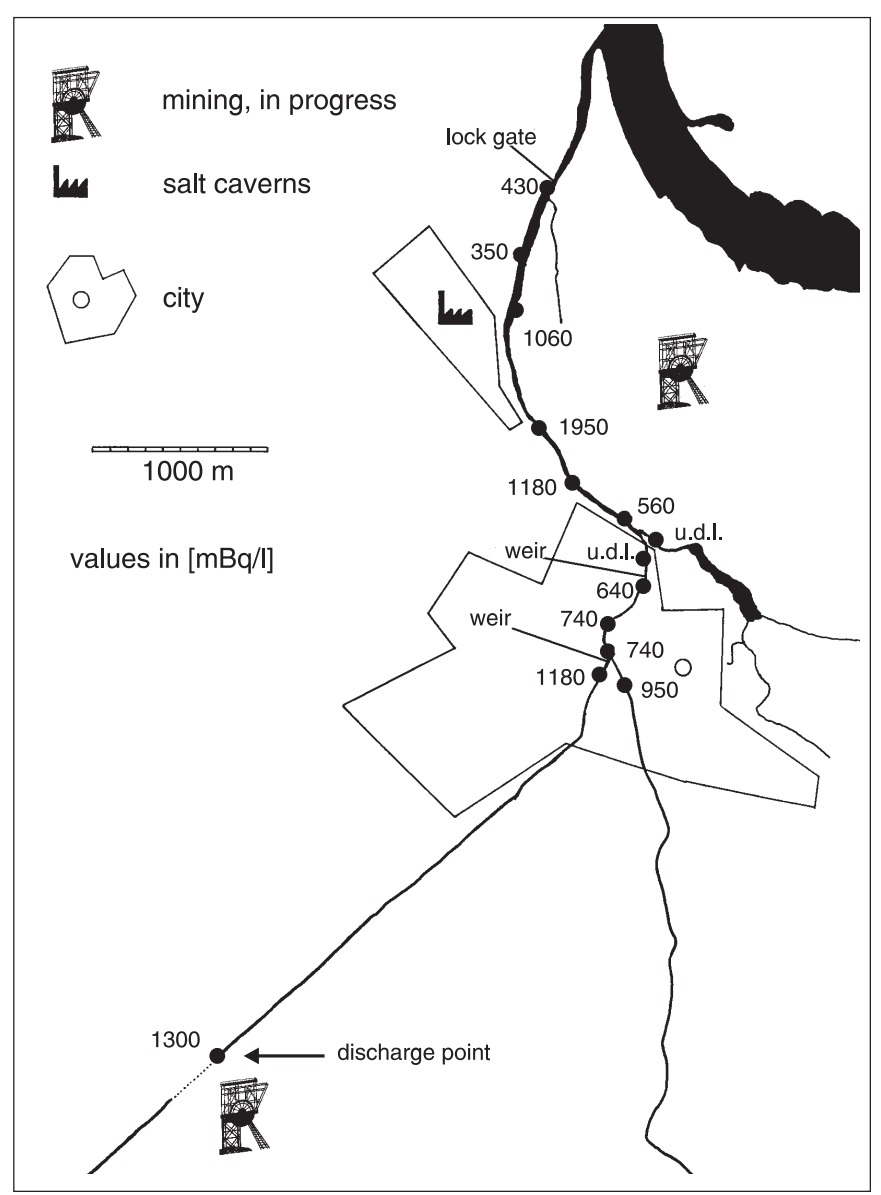

Fig. 2. - Increasing Rn-222 concentration in river water after degassing due to the emanation of Ra-226-rich sediments in the river bed (u.d.l.: under detection limit).

gamma dose rate comes up to $6000 \mathrm{nSv} \mathrm{h}{ }^{-1}$. In dependence on the thickness of the sediment, doses up to $10000 \mathrm{nSv} \mathrm{h}{ }^{-1}$ (surface dose) were measured. Although the incoming water is diluted and impoverished in ${ }^{226} \mathrm{Ra}$, the pollution is still detectable on pastures and fields several kilometres downstream the colliery. Precipitated radiobarite accumulates downstream the discharge point and leads to activity concentrations of over $1000 \mathrm{~Bq} \mathrm{~kg}{ }^{-1}{ }^{226} \mathrm{Ra}$, five times higher than a recommendation of the German Commission for Radiological Protection (SSK) [10]. The sewage sludge, formed in clarification plants along the sewer Emscher who draws off about 43 millions $\mathrm{m}^{3} \mathrm{a}^{-1}$ pit water, contains about $1600 \mathrm{~Bq} \mathrm{~kg}^{-1226} \mathrm{Ra}$.

Figure 1 exemplarily shows an area near a colliery at the left-hand side of the river Rhine with a distinct contamination along a small river. One could see that the highest contamination occurs in the area of first contact with sulphate-bearing surface water, a clearly lower contamination downstream because of canalisation of the river and a wide area with enhanced gamma-radiation because of the low rapidity of water flow, and therefore a higher sedimentation rate, upstream the junction into the river Rhine. 
TABLE I. - Ratios of different measuring parameters in hard-coal and brown-coal mining districts. The upper part of the diagram shows data from brown-coal mining districts, the lower part illustrates data from hard-coal mining districts. Sed.: sediment.

\begin{tabular}{|c|c|c|c|c|c|c|}
\hline & \multicolumn{2}{|c|}{$\begin{array}{l}{ }^{222} \mathrm{Rn}^{-} \\
\text {exhalation } \\
\left(\mathrm{Bq} \mathrm{m^{-2 }} \mathrm{h}^{-1}\right)\end{array}$} & $\begin{array}{l}{ }^{222} \mathrm{Rn}^{-} \\
\text {emanation } \\
\left(\mathrm{Bq} \mathrm{kg}^{-1}\right)\end{array}$ & $\begin{array}{l}{ }^{226} \mathrm{Ra}^{-} \\
\text {concentration } \\
\left(\mathrm{Bq} \mathrm{kg}^{-1}\right)\end{array}$ & $\begin{array}{l}\text { emanation- } \\
\text { coefficient }\end{array}$ & $\begin{array}{l}\gamma \text {-activity } \\
(\mathrm{kcpm})\end{array}$ \\
\hline sed. & - & & 98 & 247 & 0.40 & 8.5 \\
\hline sed. & 85 & & 36 & 252 & 0.14 & 12 \\
\hline sed. & 70 & brown & 74 & 163 & 0.45 & 15 \\
\hline sed. & 373 & coal & - & - & - & 8 \\
\hline soil & 359 & & - & $200-300$ & - & 12 \\
\hline sed. & 58 & & 218 & $\max .300$ & 0.73 & 11 \\
\hline soil & 206 & & 62 & 1600 & 0.039 & 70 \\
\hline sed. & - & & 346 & 23310 & 0.015 & 600 \\
\hline sed. & 36 & & 38 & 11000 & 0.0035 & 320 \\
\hline sed. & - & hard & 283 & 32310 & 0.0086 & 500 \\
\hline sed. & - & coal & 68 & 18255 & 0.0037 & 140 \\
\hline sed. & - & & 33 & 13800 & 0.0024 & 120 \\
\hline sed. & - & & 6 & 3500 & 0.0017 & - \\
\hline
\end{tabular}

In contrast to the situation in the hard-coal mining districts the contamination along sewers and rivers in the brown-coal mining district is lower. The activity concentrations are clearly enhanced but reach $300 \mathrm{~Bq} \mathrm{~kg}^{-1}{ }^{226} \mathrm{Ra}$ as maximum value. The gamma dose rate is established to be about $120 \mathrm{nSv} \mathrm{h}{ }^{-1}$, two times higher than the geogenic background.

Increasing ${ }^{222} \mathrm{Rn}$ concentrations after degassing the water by overflowing a weir are observed near a hard-coal colliery (fig. 2). One can see that the pit water is discharged into the sewer with a ${ }^{222} \mathrm{Rn}$ concentration of $1300 \mathrm{mBq} \mathrm{l}^{-1}$. The ${ }^{222} \mathrm{Rn}$ concentration decreases along the first $4000 \mathrm{~m}$ by overflowing two weirs to a value under the detection level. Downstream the city the concentration increases due to the emanation of ${ }^{226}$ Ra-rich sediments in the river bed.

33. ${ }^{222} \mathrm{Rn}$ emanation rate and exhalation rate of soils and sediments. - A typical set of data, subdivided for the different types of coal mining, is shown in table I. Generally, the ${ }^{222} \mathrm{Rn}$ exhalation rates in the brown-coal mining district exceed the values measured in hard-coal mining districts which do not often go beyond the geogenic background [1,11]. However, ${ }^{222} \mathrm{Rn}$ emanation rates and first of all ${ }^{226} \mathrm{Ra}$ concentrations exceed the values detected in the brown-coal mining district. It is remarkable that the total gamma-radiation as well as the ${ }^{226} \mathrm{Ra}$ concentrations exceed the data from brown-coal mining in the order of one, respectively, two magnitudes, in contrast to the detected ${ }^{222} \mathrm{Rn}$ emanation rates. This observation is due to the different emanation coefficients.

\section{4. - Discussion}

The genesis of ${ }^{226}$ Ra-bearing brines can be explained by the interaction between formation water and the aquifer matrix. The process that is believed to be responsible for the transfer of ${ }^{226} \mathrm{Ra}$ into the water is a combination of alpha-particle recoil and 
chemical leaching [3]. Within the ${ }^{238} \mathrm{U}$-decay series there are three alpha-decays before ${ }^{226} \mathrm{Ra}$, which increase the availability of ${ }^{226} \mathrm{Ra}$ to enter the pore space. ${ }^{226} \mathrm{Ra}$ is adsorbed immediately at surfaces, especially on clay minerals, and an equilibrium between ${ }^{226} \mathrm{Ra}$ solved in the water and adsorbed atoms is formed. The presence of high cation concentrations, especially $\mathrm{Ba}$ ions, which are closely related to ${ }^{226} \mathrm{Ra}$, can exchange the nuclides from the adsorbents. A very important fact is that the amount of ${ }^{226} \mathrm{Ra}$ atoms is much lower than the number of competitive cations, a state that results in a high efficiency of desorption.

Recent leach experiments at our department to judge the influence and interaction of cations and anions in high mineralised brines with the aquifer matrix have shown that $\mathrm{Ba}$ is the main desorbent but demonstrate a great influence of the anions too [12]. The salinity and the number of total dissolved solids increases with the depth from which pit waters are raised. Due to that, a high concentration of ${ }^{226} \mathrm{Ra}$ in the water could be detected in upward migrating waters along geological faults. Such high amounts of ${ }^{226} \mathrm{Ra}$ in groundwater do not need the presence of a U-rich layer. This conjecture is supported by the fact that except ${ }^{226} \mathrm{Ra}$ and ${ }^{228} \mathrm{Ra}$ no other nuclide is enriched in the water [9]. Ba is enriched in the water due to the activity of a sulphate-reducing bacterium which transforms detrital barite as well.

In contact with sulphate-bearing water ${ }^{226} \mathrm{Ra}$ and $\mathrm{Ba}$ co-precipitate by diadochic incorporation into the crystal lattice of radiobarite. Because of the small number of ${ }^{226} \mathrm{Ra}$ atoms the solubility product for ${ }^{226} \mathrm{RaSO}_{4}\left(4 \times 10^{-11}\right)$ is never reached. Apart from the greatest chemical sedimentation near the mixing point, a great amount of radiobarite is transported as a suspension load and sedimentates along the river in areas with low rapidity of water-flow. The accumulation of ${ }^{226} \mathrm{Ra}$ in overbank deposits leads to a marked increase of gamma-radiation and a modified radon potential.

Because of meteorological and soil-physical factors there are difficulties in interpreting the ${ }^{222} \mathrm{Rn}$ data. Therefore, we standardised on a non-dimensional factor like "exhalation" divided by "emanation" to describe the degree of the exhalation power. High values of this factor represent higher exhalation power. Now the comparison with the soil moisture is possible: fig. 3 shows a weak correlation between low moisture content and higher exhalation power, a well-known phenomenon [13]. But a very important information of this diagram is the observation that higher exhalation

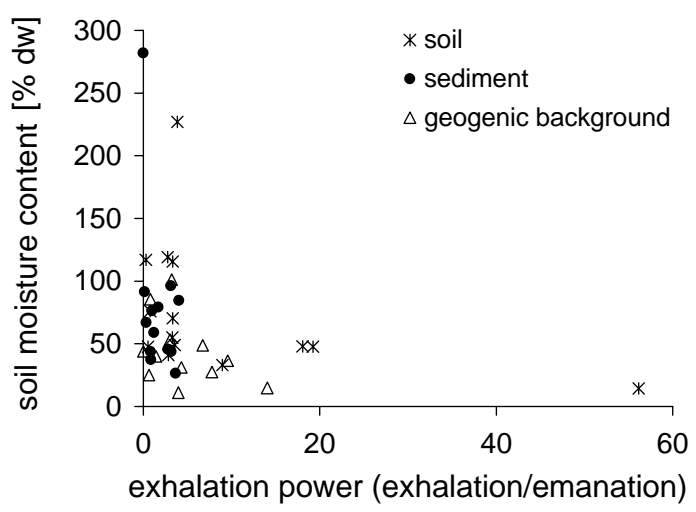

Fig. 3. - Correlation between moisture content and "exhalation divided by emanation" (non-dimensional). 


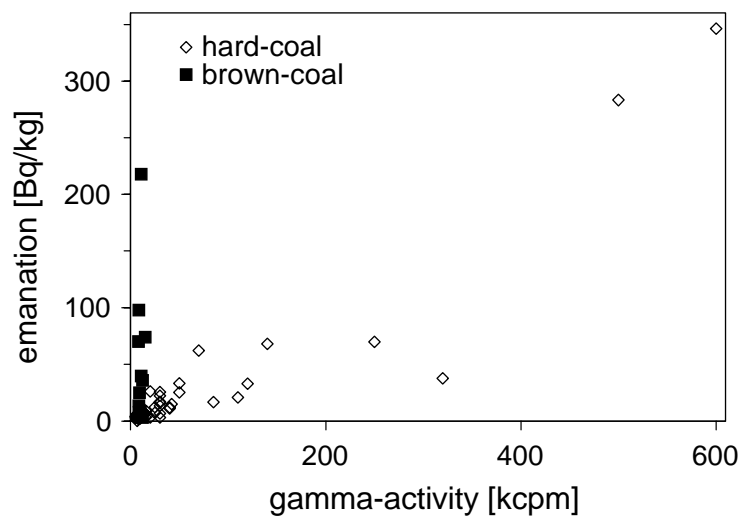

Fig. 4. - Correlation between Rn-222 emanation rate and gamma activity.

rates occur on the overbank deposits and not on the highly contaminated sediments at the river banks.

Similar results were determinated for the ${ }^{222} \mathrm{Rn}$ emanation rate of sediments and soil samples (fig. 4). There is a weak positive correlation between the gamma activity and the ${ }^{222} \mathrm{Rn}$ emanation rate. But in comparison to that the coal mining districts (hardand brown-coal) show a different behaviour. Although the samples from brown-coal mining are less contaminated with ${ }^{226} \mathrm{Ra}$ they reach higher emanation rates than the clearly contaminated samples from hard-coal mining. The non-dimensional factor to describe this phenomenon is the emanation coefficient, often called emanation power. The low emanation coefficient analysed for samples from hard-coal mining (table I) is due to the diadochic incorporation of ${ }^{226} \mathrm{Ra}$ in the very dense crystal lattice of barite. ${ }^{222} \mathrm{Rn}$ is fixed strongly in the mineral. The occurrence of pelitic coal particles from coal washing in sediments and soils seems to be responsible for lower values too because the coal adsorbs emanating ${ }^{222} \mathrm{Rn}$. In contrast to this chemical bond in a crystal lattice, in sediments influenced by brown-coal mining ${ }^{226} \mathrm{Ra}$ is adsorbed at the surface of ferric hydroxides and ${ }^{222} \mathrm{Rn}$ can easily emanate [14].

\section{5. - Conclusion}

The emission of ${ }^{226} \mathrm{Ra}$ through high mineralised brines is detectable in a wide area in the vicinity of coal mines. Two different mechanisms of setting ${ }^{226} \mathrm{Ra}$ in minerals take place. Both chemical bond or adsorption of ${ }^{226} \mathrm{Ra}$ lead to characteristic proportions between exhalation rate, emanation rate and gamma activity in different coal mining districts.

Further investigations have to quantify the additional dose to the population. Spreading of sediments and sewage sludge on pastures and fields and uptake by plants and animals are possible pathways to humans.

We owe many thanks to Mr. H. KLös, Environmental Protection Agency, for supporting this research project partly, and for doing the gamma spectrometry analysis. Thanks to Mrs. S. ScHMID for her help during field work. 


\section{REFERENCES}

[1] Gans I., Fuhrmann E., Weller E. and Wollenhaupt H., Radium in waste water from coal mines and other sources in the Federal Republic of Germany, in VoLSA K. et al. (Editors), Natural Radiation Environment (New Delhi, Wilay Eastern Ltd.) 1982.

[2] Lebecka J., Chalupnik S., Mielnikow A., Wysocka M., Lukasik B., Molenda E. and CICHY T., Utilisation of industrial waste products for purification of mine waters of radium, Proceedings Technology enhanced natural Radiation caused by non-uranium mining (Central Mining Institute, Katowice) 1996, pp. 321-330.

[3] Kraemer T. F. and REID D. F., The occurrence and behavior of radium in saline formation water of the U.S. gulf coast region, Isotope Geosci., 2 (1984) 153-174.

[4] Meßanleitung UmweltradiOaktivität, Verfahren zur Bestimmung von Radium-226 in Trinkwasser und Grundwasser, Vol. 1 (Gustav Fischer, Jena) 1992, p. 1.

[5] LuCAS H. F., Improved low-level alpha scintillation counter for radon, Rev. Sci. Instrum., 28 (1957) 680.

[6] Pellegrini D., Stammose D., Biton G. and Chambaudet A., Effect of moisture content and particle size fractionation on radon emanation from uranium mill tailings, in BARNET I. and Neznal M. (Editors), Radon investigation in the Czech Republic VI and the third international workshop on the geological aspects on radon risk mapping (Czech Geological Survey \& Radon corp., Prague) 1996, pp. 99-108.

[7] Feige S., Radionuklid-Kontamination von Wässern, Sedimenten und Böden durch den Steinkohle- und Braunkohlebergbau, unpublished diploma thesis, University of Essen (1997).

[8] WedewardT M., Hydrochemie und Genese der Tiefenwässer im Ruhr-Revier, PhD Thesis, University of Bonn (1995).

[9] Schweer G., Aktivitätsmessungen an Sedimenten des Ruhrgebietes in Hinblick auf deren Datierung, unpublished diploma thesis, Fachhochschule Aachen (1995).

[10] Bieshold H., Kindt A. and EtTenhuber E., Untersuchung bergbaulicher Hinterlassenschaften, atw, 41 (1996) pp. 98-102.

[11] WiEgand J. and Feige S., Radon-Messungen in den Zuflüssen der Erft und weiteren linksrheinischen Vorflutern zur Ermittlung der Radioaktivitätsquellen, Final report (unpublished), Env. Prot. Agency NRW. (1996).

[12] Kuschkowitz T., Experimentelle Untersuchungen zur Radium-Mobilität in salinaren Wässern, unpublished diploma thesis, University of Essen (1998).

[13] Washington J. W. and Rose A. W., Temporal variability of radon concentration in the interstitial gas of soils in Pennsylvania, J. Geophys. Res., 97 (1992) 9145-9159.

[14] Hanslik E. and Mansfeld A., Removal of radium from drinking water, in The environmental behaviour of radium (International Atomic Energy Agency, Vienna) Vol. 2, Chapts. 2-5 (1990) pp. 228-268. 